\title{
Academic Leadership And Organizational Commitment In Public Universities Of Malaysia
}

\author{
Muhammad Hasmi Abu Hassan Asaari \\ Universiti Sains Malaysia \\ Ashish Dwivedi \\ University of Hull \\ Alan Lawton \\ Monash University \\ Nasina Mat Desa \\ Universiti Sains Malaysia
}

doi: 10.19044/esj.2016.v12n16p329 URL:http://dx.doi.org/10.19044/esj.2016.v12n16p329

\begin{abstract}
The purpose of this paper is to examine the relationship between academic leadersip and organisational commitment. The independent variable, academic leadership, is formed by visionary, adaptable to change, competency, effective leadership, transformational style, and charisma while the dependent variable is organisational commitment. A total of 251 questionnaires were obained from faculty members of public universities in Malaysia, which yielded a response rate of $41.8 \%$. The results reveal that academic leadership, namely adaptable to change, transformational style and charisma, are significantly and positively related to organisational commitment. Theoretically, this paper contributes to the literature on academic leadership and organizational commitment. Practically, top management of public universities should consider trainings and courses on change, transformation, and charisma that boost academic leadership of faculty members. In conclusion, this paper reveals the importance of change, transformation, and charisma as factors of academic leadership in affecting organisational commitment of faculty members of public universities in Malaysia.
\end{abstract}

Keywords: Academic leadership, organizational commitment, faculty members, public universities

\section{Introduction}

Faculty members of public universities in Malaysia are given responsibilities and accountabilities toward themselves, students, the 
university, community and government. Faculty members need to cope with those responsibilities and accountabilities. According to a decade of literature, the faculty members' responsibilities take the form of teaching (Butler, 2000), scholarship (Aboudan, 2011), supervision (Bulger, 2006), research (Jones, Davis \& Price, 2004), consultancy (Cater-Steel, Hine \& Grant, 2010), civic engagement and community outreach participation (Hollander \& Saltmarsh, 2000), and publishing books and journal articles (Bates, Waldrup, Shea \& Heflin, 2011).

Further, faculty members of public universities are entrusted to train future generations of scholars, scientists and practitioners (Crow, 2010). They use their expertise in delivering knowledge and skills to those future generations. In fulfilling trust, faculty members need capabilities of academic leadership. Moreover, these responsibilities and accountabilities on faculty members could affect their academic leadership and organizational commitment.

Leadership is, basically, the process of social influence from superior to subordinates; in other words, the ability to exert influence over others (Kochan, Schmidt \& DeCotiis, 1975). Leadership is also seen as the major driving force behind this continuous recognition of performance. Moreover, Mclaurin and Amri (2008) stated that leadership is a dynamic relationship which is based on mutual incluence between leaders and followers which results in a higher level of motivation and technical development as it promotes changes.

Leaders with effective leadership can work together with their followers to achieve goals, can function well together and can adapt to changing demands from external forces (Nahavandi, 2009). Many studies attempt to explore the leadership effect on work outcomes such as employee commitment (Lee \& Ahmad, 2009), job satisfaction (Lee \& Ahmad, 2009; Duffield, Roche, O'Brien-Pallas \& Catling-Paull, 2009), turnover intention (Ansari, Hung \& Aafaqi, 2007), performance (Porr \& Field, 2006; Kivipold \& Vadi, 2010), attitudes (Martin \& Bush, 2003), planning (Wilson \& Eilertsen, 2010), and personal development (Mannion, 2009); and, again, the list is not exhaustive.

Academic leadership has not received much coverage in the reviews, especially the issue of identifying leadership approaches in higher education (Favero, 2005). Further, Askling and Stensaker (2002) state that there is much to be gained by studying the practice of leadership in higher education. Koen and Bitzer (2010) highlight the components of academic leadership that they discovered through several interviews with academic leaders. In sum, there is a need for further study on academic leadership in public organizations especially public universities. Moreover, academic leadership has not been much associated with organizational commitment. 
Therefore, this paper aims to examine the impact of the academic leadership landscape on organizational commitment of faculty members. This paper uses five measures, namely visionary, adaptable to change, effective leadership, transformational style, and charisma, for quantifying academic leadership. On the other hand, organizational commitment is used to measure the faculty members' level of commitment toward their organization.

\section{Literature Review \\ University's Leadership}

Higher education institutions are based on a strong departmental model. The departmental structure is further reinforced by the fact that tenure and promotion decisions for faculty are initiated by the departments and these departments compete with each other for university resources (Sirvanci, 2004). Further, administrators of academic departments are considered by many experts to be indispensable to the effectiveness of postsecondary institutions (Jones \& Holdaway, 1996). As such, academic positions are important in a university. Thus, leadership is highly regarded in this context. Rowley and Sherman (2003) draw attention to the issue of matching organizational needs with human resource capabilities in a university. Further, the success of higher education institutions is dependent on effective and competent leaders (Bisbee, 2007). In the reviews, several different terminologies are used such as higher education institutions, colleges and universities; and they will be used interchangeably. But in general the term universities will be used.

Faculty members will be the focus of this study. Leadership in higher education involves a relationship or a followership (Koen \& Bitzer, 2010). Jones and Holdaway (1996) reveal the difficulties they faced when juggling the administrative, political and entrepreneurial components of their position. These faculty administrators need a broad array of sophisticated managerial skills and the attributes of academic leadership. In a similar vein, Kekale (2003) states that management and leadership have become necessary for academic leadership due to political and economic pressures, the increasing size and scope of university business and increased demand for accountability. The additional challenges facing academic leaders include leading institutional renewal, attracting and retaining top quality faculty, staff and students, embracing learning technologies, meeting increasing demands from the public, funding agencies, employers, students and university employees and seeking new and alternate sources of funds and financial models. Thus there is a need for academic leaders who thrive on the challenge of change, who foster environments of innovation, who encourage trust and learning, and who can lead themselves, their constituents, and their 
units, departments and universities successfully into the future (Brown, 2001).

Kekale (2003) describes academic leaders metaphorically as thermostats: he/she does not have to control or direct everything, but instead must concentrate on promoting the most important strategic issues. During normal times, the leader supports basic work conditions, maintains a creative working atmosphere and tries to keep things in a proper balance and within the range of normal operational conditions. The leader may have to contribute more actively to the process by providing support, advice or more direct leadership during serious problems (Kekale 2003).

Reflecting on the work by Rowley and Sherman (2003), they indicate the working frame of faculty members in a university and in a faculty/school. They state that academic leadership at a university can be viewed from the perspective of leadership levels and leadership settings. The leadership levels consist of leadership positions such as department chairs, deans and vice chancellor/deputy vice chancellors. Leadership settings consist of administrative departments, academic departments, student and faculty organization (Rowley \& Sherman, 2003). Further, they link the academic levels and academic settings where department chairs lead academic departments, deans lead faculty organizations and vice chancellor/deputy vice chancellors lead administrative departments.

First, a department chair will be the leader in the department (Rowley \& Sherman, 2003; Bisbee, 2007). This leadership is temporary because the faculty member serves for few years. They will return to their regular teaching and research duties as a regular member of the faculty. The person does not feel as though he/she is leaving the faculty; instead, he/she is taking the additional managerial responsibilities only for a short time period. Unfortunately, the person who is responsible for providing leadership is not necessarily willing to be a leader. Further, he/she knows that leadership must be highly collegial or it will be very difficult to return to a faculty position once the time ends. Most department chairs do not aspire to become department chairs, nor do they consider successful management and leadership part of their career paths (Brown, 2001). Further, Brown claims that department chairs traditionally complain about management's rejection of collegiality, being burdened with administrative tasks and having valuable time taken from their academic work and being subject to increasingly intrusive assessment processes. In academic departments, leadership is required for both administrative and academic functions. Faculty members placed in these roles do not necessarily aspire to managerial or leadership positions, especially for department chairs. Rowley and Sherman (2003) note that many faculty members, thus, end up in both managerial and leadership roles without ever having aspired to them. This creates the unique challenge 
of leadership in the university. They also note that all faculty members who have management responsibilities need to have a clear understanding of their leadership roles and responsibilities and to step up to the challenges they face to help the campus and to progress toward mission fulfilment.

Second, the dean is also a faculty member but one who is willing to give up teaching and research responsibilities to become a full-time administrator. Most deans return to the faculty when their terms in office have expired. In the dean's job leadership is complicated by the desire to lead the school or college to new levels of accomplishment and excellence while keeping in mind he/she will return to the faculty. Here, the dean's leadership is more managerial and professional and similar to that of managers in business organizations.

Finally, the vice chancellor (also deputy vice chancellor) is also a previous faculty member. He/she may have entered the deanship and later moved up into the top administrative position in the university. Some top administrators go on to other universities to pursue higher levels of responsibility and authority. But, there are some top administrators who return to the faculty at the end of their term of office. In the administrative departments, administrators (such as vice chancellors and deputy vice chancellors and deans) are the top rank of the campus administration. They lead the university towards higher goals and accomplishments (Rowley \& Sherman, 2003).

Nevertheless, basic faculty members have some responsibilities that involve a degree of management and leadership (Rowley \& Sherman, 2003). These responsibilities are reflected in their own classroom such as managing their classroom and even guiding students and helping them in their learning. Further, faculty members may also have responsibilities in a group of research projects. Faculty members often assume leadership roles in their respective functions and as members of teams or projects (Rowley \& Sherman, 2003). Further, the role of the academic leader is very different from that of regular faculty members even though faculty members are often asked to serve in these capacities.

Some faculty members are not interested in holding any academic administrative positions. Due to the nature of academia faculty members are rewarded for efficiency and effectiveness in their disciplines and not for taking and excelling in leadership roles (Bisbee, 2007). This causes challenges for universities when identifying faculty members who are willing to accept the responsibility of leadership roles to serve and be involved in meaningful change (Rowley \& Sherman, 2003) to their department, faculty and university. 


\section{Academic Leadership}

Based on reviews, academic leadership is defined according to the studies context. McNamara (2009) studies academic leadership in nursing and states that academic leadership is directed towards building meaningful partnerships between clinical and academic settings and providing the conditions of possibility for the development of clinician-educators who operate at the research-practice interface. Meanwhile, Zhao and Ritchie (2007), in their investigation of academic leadership in tourism research, state that academic leadership refers to the superior capability of some tourism scholars to communicate their research works in accredited tourism journals. Strathe and Wilson (2006) claim that faculty members have historically served as the source of academic leadership through their degree programs for teaching, research and scholarship, and service responsibilities.

Further, Murphy (2003) states academic leadership is a complex and demanding role with significant stress and high burnout and turnover rates. Askling and Stensaker (2002) refer to academic leadership as a role carried out formally, almost as an obligation. Further, they look at academic leadership by seeing leadership as a process of social interaction guiding individuals and groups towards particular goals. Marshall, Adams, Cameron and Sullivan (2000) term academic leadership as a collection of tasks or functions performed by individuals appointed to formal positions of responsibility within universities (i.e. vice chancellor, dean and/or head of discipline/department). Meanwhile, Jones and Holdaway (1996) define academic leadership based on activities undertaken by departmental heads, namely programme activities, faculty-related activities and personal academic activities.

\section{Visionary}

Faculty members need visionary leadership to lead their universities. In the context of globalization, faculty members in the university need to foresee the challenges and opportunities ahead of them. These opportunities must be capitalized and challenges must be minimized. McLaurin (2008) indicates that "effective leaders have a clear and definitive vision as to what performance ought to be and how it can be enhanced to reach that target. This vision has to be communicated to the personnel to help them achieve success.” A leader with visionary thinking would look for the betterment of the persons, groups and organization that they lead. A visionary leader talks optimistically about the future. This person also elaborates what needs to be accomplished. In the context of a university, a leader can be seen as being visionary when he/she acts by promoting the organization's vision by inspiring their follower (Yoeli \& Berkovich, 2010). They assert that a 
leader's personal vision has an important role for developing a shared vision with other faculty members (Yoeli \& Berkovich, 2010).

\section{Adaptable to Change}

Leadership should manage changes that surround them. Marshall (2007 in Koen \& Bitzer, 2010) states "it is not the strongest of the species that survives, or the most intelligent; it is the one that is most adaptable to change.” Leaders in the university context need to be adaptable to change in administering the university towards resistance and challenge. Further, leadership in a university is important in achieving organizational objectives. In order to do so adaptive leadership (Randall \& Coakley, 2007) is needed to instigate change as and when required. Further, adaptability of faculty members is associated and caused effective leadership (Hotho et al., 2008).

\section{Effective Leadership}

Good management is associated with effective leadership. Fitsimmons (2007) distinguishes between good leadership and good management. Good leadership is dynamic, whereby good management is static. Good management and good leadership are required for effective leadership. Effective leadership can be seen in good management (Bennett, 2003). Good management provides the framework from which to launch successful leadership strategies with a sense of order and consistency (Gokenbach, 2003). Further, good management condones the successful transfer of management knowledge (McKnight, 2007). Effective leadership is expected to produce a desired or intended result as determined by the organization's objectives. Further, effective leadership promotes a culture that engages employee and clients and encourages focus, energy and spirit (Turner, 2007/2008). Riggio and Reichard (2008) state the role of emotional and social skills in effective leadership. They hold that emotional skills and complementary social skills are essential for effective leadership. Meanwhile, Nichoson, Sarker, Sarker and Valacich (2007) conclude that behavioural and trait approaches are dominant in explaining effective leadership. They state national culture plays a role in determining what is considered effective leadership.

\section{Transformational Style}

Transformation is known as a marked change in nature, form, or appearance. In the context of leadership, a leader is the person, who makes changes in the nature, form and appearance of work and people in an organization. The scholarly research on leadership concentrates on the transformational paradigm (Koen \& Bitzer, 2010). Further, transformational leadership focuses on "the interactions between leaders and followers, an 
emerging idea significant in the university context” (Kezar, Carducci \& Contreres-McGavin, 2006 in Koen \& Bitzer, 2010, p.3). Transformational leaders encourage employees, build trust, and gain admiration, loyalty and respect from subordinates (Limsila \& Ogunlana, 2008). Transformational leadership is associated with effective leadership and visionary leadership is associated with long term direction and planning capacity (Jogulu \& Wood, 2008). Transformational leadership is more effective, productive, innovative and satisfying to followers as both parties work towards the good of the organization propelled by shared visions and values as well as mutual trust and respect (Lo et al., 2009).

\section{Charisma}

Charisma is a human trait. It is found in persons whose personalities are characterized by charm and magnetism, along with innate and powerfully sophisticated abilities of interpersonal communication and persuasion. Someone who is charismatic is said to be capable of using their personal being, rather than just speech or logic alone, to interface with other human beings. Charisma is associated with the person's way of dealing with others. Being a leader, charismatic people act beyond their own self-interest for the good of other persons or the group. Simultaneously, the person will display a sense of power and confidence. Through power and confidence, the leader instils pride in others for being associated with him/her. Moreover, Lee and Liu (2011) conclude that charismatic leaders are able to express themselves fully. They also know who they are, what their advantages and disadvantages are and how to completely use their advantages and compensate for their disadvantages. Moreover, they know what they want, why they want it and how to communicate what they want in order to gain cooperation and support from others.

\section{Organizational Commitment}

Organizational commitment is commonly conceptualized as an affective attachment to an organization characterized by shared values, a desire to remain in the organization, an action characterized by shared values, a desire to remain in the organization, and a willingness to exert effort on its behalf (Mowday et al., 1979). Further, organizational commitment refers to the degree of attachment and loyalty felt by individual employees to the organization (Mowday et al., 1979; Alas \& Edwards, 2006). Becker (1960) views organizational commitment as a reflection of recognized, accumulated interest that binds one to a particular organization (Bhuian \& Islam, 1996).

Other scholars view organizational commitment as an internal feeling, belief, or set of intentions that enhances an employee's desire to 
remain with an organization (Buchanan, 1974; Bhuian \& Islam, 1996) and an employee's feeling of obligation to stay with the organization (Bhuian \& Islam, 1996), a strong desire to remain a member of the particular organization and given opportunities to change jobs (Bhuian \& Islam, 1996). Moreover, Yiing and Ahmad (2009) discovered that leadership styles have a positive and significant relationship with organizational commitment. Employees who are highly committed to their organizations contribute more effectively to company growth and success. The length of time the employees remain with the organization should correlate with their degrees of attachment and loyalty.

This paper investigates the relationship and the impact of academic leadership construct on organizational commitment. The academic leadership construct comprises of visionary, adaptable to change, effective leadership, transformational style, and charisma. Thus, the hypotheses being developed as below:

$\mathrm{H}_{1}$ : Visonary has a positive effect on organizational commitment.

$\mathrm{H}_{2}$ : Adaptable to change has a positive effect on organizational commitment.

$\mathrm{H}_{3}$ : Effective leadership has a positive effect on organizational commitment.

$\mathrm{H}_{4}$ : Transformational style has a positive effect on organizational commitment.

$\mathrm{H}_{5}$ : Charisma has a positive effect on organizational commitment.

\section{Methodology}

This paper explores the context of faculty members in the twenty Malaysian public universities. Moreober, the population frame is faculty members employed in public universities. The list of faculty members is obtained from the university's academic staff web sites. Data mining of faculty member email addresses is conducted. Simple random sampling was used. The unit of analysis is the individual faculty member of the public university. The data is gathered from each individual and treat each response as an individual data source (Sekaran, 2003). A total of 251 useable questionnaires were examined using SPSS, which yielded $41.8 \%$ of response rate.

Academic leadership is measured using the Leadership Behaviour Development Questionnaire - Form XII (LBDQ-XII) (Stogdill, 1963). The LBDQ-XII Cronbach's alpha of the samples was 0.54 to 0.86 across the nine time periods. The organizational commitment uses the Organizational Commitment Questionnaire (OCQ) originated from the work of Mowday et al. (1979). The OCQ was used widely in research and was shown to have acceptable psychometric properties (Mowday et al., 1979). The original 
OCQ instrument consists of 15-items and Cronbach's alpha was 0.82 to 0.93 . Based on the instrument adaptation and adoption, the highest Cronbach's alpha was 0.95 (Karia \& Asaari, 2006).

\section{Analysis and results}

Demographically, the questionnaire responents consist of 111 males (45.3\%) and 134 females (54.7\%). The majority of the respondents are married as indicated by 216 respondents (89.6\%). Meanwhile single respondents comprise 23 people (9.5\%).

Reliability analyses were conducted on each of the acaedmic leadership factors, namely visonary, adaptable to change, competency, effective leadership, transformational style and charisma. One item of adaptable to change had been dropped to increase the alpha value from 0.68 to 0.71 . Organizational commitment remains.

Correlations analysis was done on the components of academic leadership and organizational commitment. The relationship between servant leadership and organizational commitment was investigated using correlation coefficient. Preliminary analyses were performed to measure no violation of the assumptions of normality, linearity and homoscedasticity. Overall, there were strong correlation $(\mathrm{p}<0.01$ and $\mathrm{p}<0.05)$ between variables.

In Table 1, regression analysis was conducted between academic leadership and organizational commitment. The $\mathrm{R}^{2}$ value indicated $23 \%$ for the organizational commitment, which was explained by academic leadership. This mean $77 \%$ of the variance for organizational commitment was explained by other unknown variables that have not been explored. The multiple regression model $(\mathrm{F}=13.31, \mathrm{p}<0.1)$ was proven to be a significant model due to the $\mathrm{F}$ ratio being significant in predicting organizational commitment.

Table 1: Simple Regression between Servant Leadershipand Organizational Commitment

\begin{tabular}{|c|c|c|}
\hline \multirow{2}{*}{ Academic Leadership } & \multicolumn{2}{|c|}{ Organizational Commitment } \\
\cline { 2 - 3 } & Std Beta & Sig. \\
\hline Visionary & 0.08 & 0.36 \\
\hline Adaptable to Change & 0.11 & 0.10 \\
\hline Effective Leadership & 0.10 & 0.18 \\
\hline Transformational Style & 0.15 & 0.09 \\
\hline Charisma & 0.16 & 0.08 \\
\hline $\mathrm{R}^{2}=$ & 0.23 & \\
Adjusted $\mathrm{R}^{2}=$ & 0.21 & \\
Std Error $=$ & 0.60 & \\
F Statistics $=$ & 13.31 & \\
Sig F = & 0.00 \\
\hline
\end{tabular}


Overall, the $\mathrm{F}$ ratio result presented that the combination of organizational commitment was a good fit in predicting academic leadership. Looking at the individual predictor, adaptable to change $(\beta=0.11, p<0.1)$, transformational style $(\beta=0.15, \mathrm{p}<0.1)$ and charisma $(\beta=0.16, \mathrm{p}<0.1)$ were significant predictors for organizational commitment. This explained that adaptable to change, transformational style, and charisma were factors of academic leadership that were positively related to organizational commitment. Therefore, hypotheses $\mathrm{H}_{2}, \mathrm{H}_{4}$, and $\mathrm{H}_{5}$ are accepted.

\section{Discussion and conclusion}

This paper indicates that academic leadership, namely visionary, adaptable to change, effective leadership, transformational style and charisma, have a good indicator for organizational commitment among faculty members in public universities. Thus, it is an impetus for university top management to ensure that their faculty members do get the relevant trainings, courses, exposures, and retoolings that could enhance their factors of academic leadership. Moreover, these activities could be directed to the Human Resource Management of public universities to be conducted.

Moreover, results have indicated that there is consistent support for factors of academic leadership in realtion to organizational commitment that support the suggested hypotheses. Thus, faculty member that realized their universities provide actvities in promoting adaptable to change, transformational style, and charisma will have a significant impact on their organizational commitment. This could benefit public universities in the long run.

Academic leadership and organizational commitment play important factors among faculty members in public universities. Moreover, the contribution of perceived organizational support will enhance further the faculty members' organizational commitment. Thus, the results provide practical implications for the universities top management to understand the faculty members' academics leadership and organizational commitment that could lead to public universities' performance in the eyes of parents and potential students.

\section{References:}

dAboudan, R. Engage Them, Don't Enrage Them - Student Voices and What It Takes to Participate. English Language Teaching, 4(1), 128-134, 2011.

Agarwal, S. \& Ramaswani, S.N. Affective organizational commitment of salesperson: an expanded model, Journal of Personal Selling and Sales, 13(2), 49-70, 1993. 
Alas, R. \& Edwards, V. Work-related attitudes in Finno-Ugrian countries: Estonia, Finland and Hungary. AIB-SE (USA) 2006 Annual Meeting. Clearwater Beach, FL, USA, 2006.

Ansari, M. A., Hung, D. K. M. \& Aafaqi, R. Leader-member exchange and attitudinal outcomes: role of procedural justice climate. Leadership \& Organization Development Journal, 28(8), 690-709, 2007.

Askling, B. \& Stensaker, B. Academic leadership: prescriptions, practices and paradoxes. Tertiary Education and Management, 8, 13-125, 2002.

Bates, H. L., Waldrup, B. E., Shea, V. J. \& Heflin, W. L. Accounting Editorial Board Membership And Research Output. Journal of Business \& Economic Research, 9(3), 39-46, 2011.

Becker, H. S. Notes of the concept of commitment. American Journal of Sociology, 66, 32-42, 1960.

Bennett, N. Assessing the impact on practice of professional development activities. In Bennett, N. \& Anderson, L. (Eds.) Rethinking Educational Leadership. New Delhi: Sage, 2003.

Bhuian, S. N. \& Islam, M. S. Continuance commitment and extrinsic job satisfaction among a novel multicultural expantriate workforce. Mid-Atlantic Journal of Business, 32(1), 35-46, 1996.

Bisbee, D. C. Looking for leaders: current practices in leadership identification in higher education. Planning and Changing, 38(1\&2), 77-88, 2007.

An Academy. Economic Inquiry, 25(4), 645-657, 1987.

Brown, L. M. Leading leadership development in universities: a personal story. Journal of Management Inquiry, 10(4), 312-323, 2001.

Buchanan, B. Building organizational commitment: the socialization of managers in work organizations. Administrative Science Quarterly, 19, 533546, 1974.

Bulger, S. M. Maintaining Connections: A Web-Enhanced Approach to Undergraduate Internship Supervision. Physical Educator, 63(3), 114-125, 2006.

Butler, J. E. "Democracy, diversity, and civic engagement." Academe Online, Available: http://www.aaup.org/AAUP/CMS_Templates/AcademeTemplates/Academe Article.aspx?NRMODE=Published\&NRNODEGUID=\%7B22D47ACE249D-4562-B0EF95642507DCE0\%7D\&NRORIGINALURL=\%2FAAUP\%2Fpubsres\%2Faca deme\%2F2000\%2FJA\%2FFeat\%2Fbutl.htm\&NRCACHEHINT=NoModify Guest [Accessed 10 October 2009], 2000.

Cater-Steel, A., Hine, M. \& Grant, G. Embedding IT Service Management in the Academic Curriculum: A Cross-national Comparison. Journal of Global Information Technology Management, 13(4), 64-92, 2010. 
Crow, M. Organizing Teaching and Research to Address the Grand Challenges of Sustainable Development. Bioscience, 60(7), 488-489, 2010.

Duffield, C., Roche, M., O'Brien-Pallas, L. \& Catling-Paull, C. The implications of staff 'churn' for nurse managers, staff, and patients. Nursing Economics, 27(2), 103-110, 2009.

Eddy, E. R., Lorenzet, S. J. \& Mastrangelo, A. Personal and professional leadership in a government agency. Leadership \& Organization Development Journal, 29(5), 412-426, 2008.

Erickson, A. L. Ethical leadership and the public trust. Public Manager, 35(1), 62-63, 2006.

Favero, M. D. The social dimension of academic discipline as a discriminator of academic deans' administrative behaviors. Review of Higher Education, 29(1), 69-96, 2005.

Fitsimmons, G. Library leadership, The Bottom Line: Managing Library Finances, 20(4), 172-173, 2007.

Gokenbach, V. Infuse management with leadership. Nursing Management, 34(1), 8-17, 2003.

Hancock, T. M. The business of universities and the role of department chair. International Journal of Educational Management, 21(4), 306-314, 2007.

Hollander, E. L. \& Saltmarsh, J. "The engaged university." Academe Online, Available:

http://www.aaup.org/AAUP/pubsres/academe/2000/JA/Feat/holl.htm

[Accessed 9 September 2009], 2000.

Horner, M. Leadership theory: past, present and future. Team Performance Management, 3(4), 270-287, 1997.

Hotho, S., Mcgoldrick, J. \& Work, A. New perspective on academic leadership moving the research agenda. Academic Leadership: The Online Journal, 6(3), 1-19, 2008.

Jogulu, U. D. \& Wood, G. J. A cross-cultural study into peer evaluation of women's leadership effectiveness. Leadership \& Organization Development Journal, 29(7), 600-616, 2008.

Jones, A. L., Davis, S. N. \& Price, J. Preparing Future Faculty: A New Approach at North Carolina State University. Teaching Sociology, 32(3), 264-275, 2004.

Jones, D. R. \& Holdaway, E. A. Post-secondary department heads: expectations for academic leadership and authority. International Journal of Educational Management, 10(3), 10-20, 1996.

Karia, N. \& Asaari, M. H. A. H. The effects of total quality management practices on employees' work-related attitudes. The TQM Magazine, 18(1), 30-43, 2006.

Kekale, J. Academic leaders as thermostats. Tertiary Education and Management, 9(4), 281-298, 2003. 
Kezar, A. J., Carducci, R. \& Contreras-McGavin, M. Rethinking the 'L' Word in Higher Education. The Revolution of Research on Leadership. San Francisco: Jossey Bass, 2006.

Kivipold, K. \& Vadi, M. A measurement tool for the evaluation of organizational leadership capability. Baltic Journal of Management, 5(1), 118-136, 2010.

Kochan, T. A., Schmidt, S. M. \& DeCotiis, T. A. Superior-subordinates relations: leadership and headship. Human Relations, 28(3), 279-294, 1975.

Koen, M. P. \& Bitzer, E. M. Academic leadership in higher education: a 'participative' perspective from one institution. Academic Leadership: The Online Journal,

Available:

http://www.academicleadership.org/408/academic_leadership_in_higher_edu cation_a_participative_perspective_from_one_institution/ [Accessed 9 September 2009], 2010.

Lee \& Liu. Distinguishing between leader and leadership in global business." Journal of International Management, 7(1), 1-7, 2011.

Lee, H. Y. \& Ahmad, K. Z. The moderating effects of organizational culture on the relationships between leadership behaviour and organizational commitment and between organizational commitment and job satisfaction and performance. Leadership \& Organization Development Journal, 30(1), 53-86, 2009.

Limsila, K. \& Ogunlana, S. O. Performance and leadership outcome correlates of leadership styles and subordinate commitment. Engineering, Construction and Architectural Management, 15(2), 164-184, 2008.

Lo, M.-C., Ramayah, T. \& De Run, E. C. Testing the multi-dimensional nature of "new leadership" in a non-western context: the case of Malaysia. Proceedings of the Academy of Educational Leadership, 14(1), 25-30, 2009.

Mannion, K. Leadership ... for success. Leadership \& Organization Development Journal, 30(7), 639-648, 2009.

Marshall, S. Leading and managing strategic change. In Marshall, S. (Ed.) Strategic Leadership and Change in Higher Education. London: Routledge, 2007.

Marshall, S.J., Adam, M.J., Cameron, A. \& Sullivan, G. Academics' perceptions of their professional development needs related to leadership and management: What can we learn? International Journal for Academic Development, 5(1), 42-53, 2000.

Martin, C. A. \& Bush, A. J. The potential influence of organizational and personal variables on customer-oriented selling. Journal of Business \& Industrial Marketing, 18(2/3), 114-130, 2003.

McKnight, S. The expatriate library director. Library Management, 28(4/5), 231-241, 2007. 
McLaurin, J. R. Leadership in the city of gold: an Arabian adventure of modern management capabilities in the 21st. century. Allied Academics International Conference. Academy of Educational Leadership Proceedings, 2008.

McLaurin, J.R. \& Amri, M.B.A. Developing an understanding of charismatic and transformational leadership, Allied Academics International Conference. Academy of Organizational Culture, Communications and Conflict, 13(2), 15-19, 2008.

McNamara, M.S. Academic leadership in nursing: legitimating the discipline in contested spaces. Journal of Nursing Management, 17(4), 484-493, 2009.

Mowday, R. T., Steers, R. M. \& Porter, L. W. The measurement of organizational commitment. Journal of Vocational Behavior, 14, 244-247, 1979.

Murphy, J. Reculturing Educational Leadership: The ISLLC Standards Ten Years Out, Paper prepared for the National Policy Board for Educational Administration, September, 2003.

Nahavandi, A. The Art and Science of Leadership, (Fifth ed.), Upper Saddle River, NJ.: Pearson Education, Inc, 2009.

Neubert, M.J. \& Wu, J-C.C. An investigation of the generalizability of the Houghton and Neck Revised Self-Leadership Questionnaire to a Chinese context. Journal of Managerial Psychology, 21(4), 360-373, 2006.

Nicholson, D. B., Sarker, S., Sarker, S. \& Valacich, J. S. Determinants of effective leadership in information systems development teams: an exploratory study of face-to-face and virtual contexts. Journal of Information Technology Theory and Application, 8(4), 39-56, 2007.

Porr, D. \& Fields, D. Implicit leadership effects on multi-source ratings for management development. Journal of Managerial Psychology, 21(7), 651668, 2006.

Randall, L. M. \& Coakley, L. A. Applying adaptive leadership to successful change initiatives in academia. Leadership \& Organization Development Journal, 28(4), 328-335, 2007.

Riggio, R. E. \& Reichard, R. J. The emotional and social intelligences of effective leadership: an emotional and social skill approach. Journal of Managerial Psychology, 23(2), 169-185, 2008.

Rowley, D. J. \& Sherman, H. The special challenges of academic leadership. Management Decision, 41(10), 1058-1063, 2003.

Sekaran, U. Research Methods for Business: A Skill Building Approach (4th. ed.). New York, NY.: John Wiley \& Sons, Inc, 2003.

Sirvanci, M. B. TQM implementation: critical issues for TQM implementation in higher education. TQM Magazine, 16(6), 382-386, 2004. Stogdill, R. M. Manual for the Leadership Behavior Description Questionnaire - Form XII. Ohio, Ohio State University, 1963. 
Strathe, M. I. and Wilson, V. W. Academic leadership: The pathway to and from. New Directions for Higher Education, 134, 5-13, 2006.

Turner, J. Developing executive leadership in the public sector. Public Manager, 36(4), 50-55, 2007/2008.

Wilson, J. W. \& Eilertsen, S. How did strategic planning help during the economic crisis? Strategy \& Leadership, 38(2), 5-14, 2010.

Yiing, L. H. \& Ahmad, K. Z. The moderating effects of organizational culture on the relationships between leadership behaviour and organizational commitment and between organizational commitment and job satisfaction and performance. Leadership \& Organization Development Journal, 30(1), 53-86, 2009.

Yoeli, R. \& Berkovich, I. From personal ethos to organizational vision: narratives of visionary educational leaders. Journal of Educational Administration, 48(4), 451-467, 2010.

Zhao, W. \& Ritchie, J.R.B. An investigation of academic leadership in tourism research: 1985-2004. Tourism Management, 28(2), 476-90, 2007. 